\title{
Eiphosoma laphygmae, a classical solution for the biocontrol of the fall armyworm, Spodoptera frugiperda?
}

\author{
Tabea Allen $^{1} \cdot$ Marc Kenis $^{2} \cdot$ Lindsey Norgrove $^{1} \mathbb{C}$
}

Received: 10 March 2021 / Accepted: 8 May 2021 / Published online: 6 June 2021

(c) The Author(s) 2021

\begin{abstract}
The fall armyworm, Spodoptera frugiperda, an American Lepidoptera, is invasive in Africa and Asia and currently one of the most damaging cereal pests in the tropics. The ichneumonid parasitoid, Eiphosoma laphygmae, is a potential classical biological control agent. We assessed existing knowledge on biology, identified natural distributions, collated reported parasitism rates from field studies and determined which other parasitoids co-occurred. We discussed the suitability of E. laphygmae for classical biological control as well as identified limitations and knowledge gaps. We conducted a systematic literature review and had 185 hits, retaining 52 papers. Reports on the natural distribution of E. laphygmae were restricted to the American tropics, ranging from North-East Mexico to Sao Paulo State, Brazil. There were only two single and unconfirmed records of it on other hosts, suggesting that the parasitoid may be specific to $S$. frugiperda, but this needs confirmation. In fields where E. laphygmae occurred naturally, it was the second most important contributor to fall armyworm mortality, after the braconid Chelonus insularis. On average, E. laphygmae parasitized $4.5 \%$ of fall armyworm in field studies. The highest parasitism rates were from Costa Rica (13\%) and Minas Gerais, Brazil (14.5\%). However, these parasitism rates are probably largely underestimated because of likely biases in sampling and parasitism rate calculations. Eiphosoma laphygmae appeared to establish better in more diverse, weedy systems. As African farming systems often have high diversity, this may favour the establishment and parasitism of E. laphygmae if eventually introduced as a classical biological control agent.
\end{abstract}

Keywords Biological control · Eiphosoma laphygmae $\cdot$ Eiphosoma vitticolle $\cdot$ Fall armyworm · Larval parasitism · Maize $\cdot$ Spodoptera frugiperda

\section{Introduction}

The fall armyworm (FAW), Spodoptera frugiperda (J.E.Smith) (Lepidoptera: Noctuidae), is one of the most damaging pests of cereals in tropical and subtropical America (Cruz et al. 1996; Rwomushana et al. 2018). In 2016, the caterpillar was first observed in West Africa (Goergen et al. 2016) and then rapidly invaded sub-Saharan Africa, Asia and Australia (CABI 2021). It is reducing food security for millions of smallholders (Day et al. 2017). In Africa, many farmers have responded to the invasive species by using

Tabea Allen

tabea.allen@bfh.ch

1 School of Agricultural, Forest and Food Sciences (HAFL), Bern University of Applied Sciences (BFH), Länggasse 85, 3052 Zollikofen, Bern, Switzerland

2 CABI, 1 Rue des Grillons, 2800 Delémont, Switzerland synthetic insecticides, some of which are classified as highly hazardous (FAO 2018a; Tambo et al. 2019).

Biological control is an environmentally and economically safer alternative to chemical insecticides (Rebek et al. 2012; Van Driesche and Bellows 1996) and classical biological through the introduction of exotic natural enemies is particularly suitable for invasive alien species (Van Driesche and Reardon 2004; Kenis et al. 2017). Consequently, the release of native enemies in Africa and Asia should be considered (Feldmann et al. 2019; Goergen et al. 2016). An egg parasitoid of FAW, Telenomus remus (Nixon) (Hymenoptera, Scelionidae), was first envisaged for introduction, but it was found to be already present in many African countries (Kenis et al. 2019). It is now recommended to increase the $T$. remus population through regular releases in augmentative biological control programmes (Kenis et al. 2019).

In the Americas, most parasitoids of FAW develop in larvae. Eiphosoma laphygmae (Costa Lima) (Hymenoptera: Ichneumonidae), often misidentified in literature as 
Eiphosoma vitticolle (Cresson) (frequently misspelled as $E$. vitticole or E. viticolle) (Gauld 2000), is such a larval parasitoid (Fernandez-Triana and Ravelo 2007). However, before releasing an exotic species, the basic biology, host range and interaction with the host must be understood (van Driesche and Bellows 1996).

Our objectives were: to synthesize knowledge on the distribution, habitat, taxonomy and biology of E. laphygmae; to quantify impact on FAW mortality in the field; to detail pest management impacts; to determine the most important parasitoids co-occurring with E. laphygmae, estimating to total parasitism in the field; to describe previous attempts at rearing and releasing E. laphygmae; and, based on this information, to discuss the potential of E. laphygmae as classical biological control agent.

\section{Methods}

\section{Data inclusion and exclusion criteria}

We conducted a literature search on 11 November 2019 on the search engine 'Web of Science'. The search was in 'all languages' and 'all documents types' for 'all years (1900-2019)' in the Web of Science Core Collection with the key word 'Eiphosoma' and had 17 hits. We simultaneously searched in Agricola, CAB-Abstracts and Food Science and Technology Abstracts. We used the keyword 'Eiphosoma' and searched in 'all fields' with no limitations, which led to 36 initial hits. We expanded the search strategy on 12 November 2019 to Google Scholar and searched with the term 'Eiphosoma vitticolle' OR 'Eiphosoma laphygmae'; this resulted in 121 initial hits. We obtained 10 additional sources through using snowballing of a review by Molina-Ochoa et al. (2003) and through Cockerell (1913). We repeated the same search strategy on all search engines on 05 March 2021 and had two additional hits; however, both were not relevant for this study. On the same date, we additionally searched for 'Eiphosoma viticolle' OR 'Eiphosoma laphygmae' on Google Scholar resulting in 54 initial hits. After removing double hits and a first screening for relevance, 73 sources remained. We excluded 21 sources that were not about the topic or were inaccessible after exhaustive attempts to procure them. Therefore, 52 papers were included in the analysis (Fig. 1).

\section{Data extraction and synthesis}

Papers written in Spanish or Portuguese were translated to English using DeepL Translator (available at: https://www. deepl.com/translator). We followed the suggestion of Gauld (2000) and considered all species reared from Spodoptera larvae as E. laphygmae and not E. vitticolle. Many of the reviewed sources were published during 1966-2000 when the two species were considered synonyms and $E$. vitticolle considered the correct name (Gauld 2000; Townes and Townes 1966).

Data on parasitism were subject to a specific analysis. The parameters related to field parasitism, reported by different authors from the field, varied. Some described the percentage E. laphygmae contributed to all parasitized host larvae (total parasitism), while others mentioned the percentage of parasitism by E. laphygmae to all, parasitized and unparasitized host-larvae (parasitism rate). Where possible, we calculated missing information on total parasitism or parasitism rates for the analysis. Articles using artificial infestation (Figueiredo et al. 2006a, b, 2009) were excluded from the analysis on parasitism but included for assessing population dynamics. Where information on the month of data collection was given, we classified this according to the season of data collection into the first and second cropping season (Table 1).

\section{Results}

We obtained 52 hits. Thirty-five of these contained field records and contributed to assessing the species' natural distribution. In addition, information from five articles, to which we did not have access to, but were cited in MolinaOchoa et al. (2003), contributed to assessing the species natural range. From the 52 papers, six publications were categorized as containing taxonomic records on Eiphosoma. Five papers contained information on the habitat of the genus. The biology and behaviour of E. laphygmae and its impact on the host were described in 11 references. Three sources contained information on the hosts of E. laphygmae, and eight references recorded information of the effect of pest management on the parasitoid. Attempts of rearing and release of the species are described in six publications. Fifteen papers provided quantitative information on the species parasitism rate in the field and co-occurring parasitoid species (Table 2).

\section{Taxonomy}

Eiphosoma is a new world genus of Cremastinae (Ichneumonidae) with approximately 55 described, neotropical species, subdivided into 9 groups (Costa Lima 1953; Gauld 2000; Fernandez-Triana and Ravelo 2007; Onody et al. 2009). However, the genus is likely to have many more undescribed species (Gauld 2000). There have been four taxonomic reviews on Eiphosoma: Cockerell (1913), Costa Lima (1953), Gauld (2000), and Fernandez-Triana 


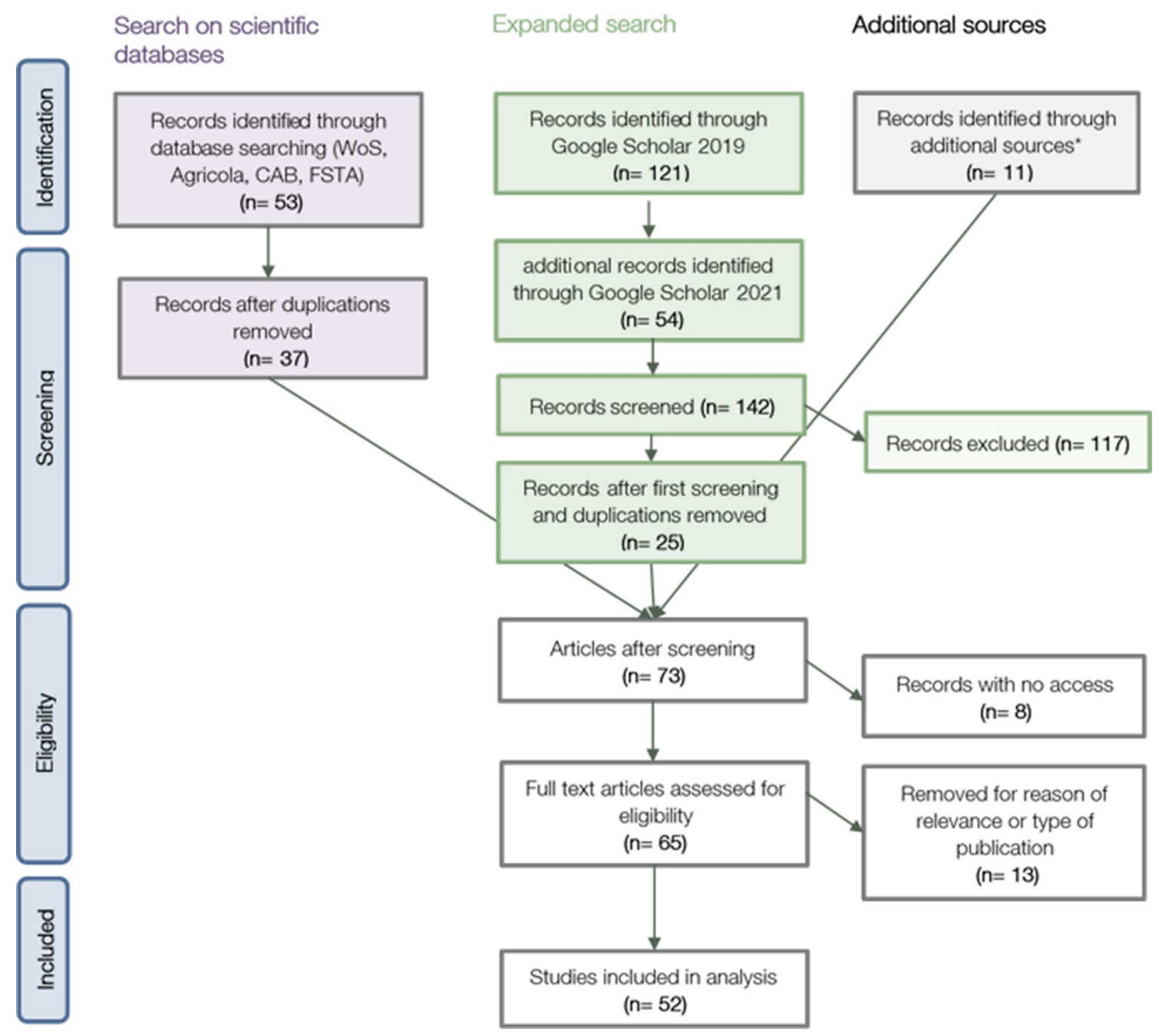

Fig. 1 PRISMA flow chart of the procedure of literature search (after Moher et al. 2009)

Table 1 Main cropping season and classification of duration of the first and second maize cropping season according to different countries and states

\begin{tabular}{|c|c|c|c|c|c|c|}
\hline Country $^{\mathrm{a}}$ & State & $\mathrm{W} / \mathrm{S}^{\mathrm{b}}$ & First season & $\mathrm{W} / \mathrm{S}^{\mathrm{b}}$ & Second season & Source ${ }^{c}$ \\
\hline BR & Minas Gerais & $\mathrm{S}$ & October-May & $\mathrm{W}$ & February-September ${ }^{\mathrm{e}}$ & Allen and Valdez (2016) \\
\hline BR & Sao Paulo & $\mathrm{S}$ & October-May & $\mathrm{W}$ & January-September ${ }^{\mathrm{e}}$ & Allen and Valdez (2016) \\
\hline BR & Maranhão & $\mathrm{T}$ & November-May ${ }^{\mathrm{e}}$ & & & Allen and Valdez (2016), FAO (2019) \\
\hline CR & & $\mathrm{T}$ & April-September ${ }^{\mathrm{e}}$ & $\mathrm{T}$ & August-January & FAO (2019) \\
\hline $\mathrm{HN}$ & & $\mathrm{T}$ & May-October ${ }^{\mathrm{e}}$ & $\mathrm{T}$ & August-February ${ }^{\mathrm{d}}$ & FAO (2019) \\
\hline MX & & $\mathrm{S}$ & April-February ${ }^{\mathrm{e}}$ & W & November-July & FAO (2019), USDA-FAS (2017) \\
\hline
\end{tabular}

${ }^{\text {a }} B R$ Brazil, $C R$ Costa Rica, $H N$ Honduras, $M X$ Mexico

${ }^{\mathrm{b}}$ Season of production: $S$ summer, $W$ winter, $T$ tropical with no distinction between summer and winter

${ }^{\mathrm{c}}$ Source for determining the seasons

${ }^{\mathrm{d}}$ Honduras has a third maize cropping season from December-April

${ }^{\mathrm{e}}$ Main cropping season in terms of production 
Table 2 Summary of reviewed sources and their classification for the results

\begin{tabular}{ll}
\hline Classification & Topic \\
\hline Distribution & Field records of E. laphygmae
\end{tabular}

Habitat

Taxonomy

Biology and behaviour

Specificity

Pest management impacts

Rearing and release of E. laphygmae
Habitat of genus Eiphosoma

Taxonomic reviews

New Eiphosoma species

Behaviour during feeding and mating

Behaviour during oviposition and attacked instars

Effect of parasitism on $S$. frugiperda and instar of E. laphygmae emergence

Immature stages of E. laphygmae

Parasitism rates and population dynamics Parasitism rates of E. laphygmae in the field and population dynamics which co-occurring parasitoids

Host species of E. laphygmae

Effect of growth regulators

Effect of green leaf volatiles

Effect of Bt-maize

Effect of insecticides

Effect of polyhedrosis virus

Records of rearing and attempted release of $E$. laphygmae

\section{References}

Armenta et al. (2003), Ashley (1979), Bastidas

et al. (2013), Canas and O’Neil (1998), Castro et al. (2009), Cave (1993), Cruz et al. (1997, 2009, 2010), Fernandes et al. (2020), Fernandez and Clavijo (1984), Figueiredo et al. (2006a, b, 2009), Gauld (2000), González-Moreno and Bordera (2012), Huis (1981), Jourdie et al. (2008), Lopez et al. (2002), Marenco and Saunders (1993), Medina et al. (1988) a , Melo and Penteado-Dias (2009), von Mérey et al. (2011, 2012), Molina-Ochoa et al. (2004), Onody et al. (2012), Pair et al. (1986), Patel and Habib (1986), Patel and Habib (1982, 1984) $)^{\mathrm{a}}$, Raven (1996) cited in Rodriguez-Berrio et al. (2009), Ruìz-Cancino et al. (2010), Salas-Marina et al. (2018), Shimbori et al. (2017), Silva et al. (2008, 2012), Silveira et al. (1987) ${ }^{\mathrm{a}}$, Valicente (1989) ${ }^{\mathrm{a}}$, Wheeler et al. (1989), Yaseen et al. (1981)

Cortez and Trujillo (1994), Cortez-Madrigal (1998), Melo and Penteado-Dias (2009), Onody et al. (2012), Porter (1983)

Cockerell (1913), Costa Lima (1953), FernandezTriana and Ravelo (2007), Gauld (2000)

Melo et al. (2012), Onody et al. (2009)

Giraldo-Vanegas and Garcia (1994a)

Ashley et al. (1982), Ashley (1983), GiraldoVanegas and Garcia (1994a, 1995), Lopez et al. (2002), Penagos et al. (2005)

Ashley (1983), Marenco and Saunders (1993), Penagos et al. (2005), Pérez-Kepp (2007), Wheeler et al. (1989)

Giraldo-Vanegas and Garcia (1992, 1994b)

Armenta et al. (2003), Cruz et al. (1997, 2009, 2010), Figueiredo et al. (2006a, b, 2009), Jourdie et al. (2008), Marenco and Saunders (1993), von Mérey et al. (2011, 2012), MolinaOchoa et al. (2004), Patel and Habib (1986), Silva et al. (2008), Wheeler et al. (1989)

Cave (1993), Gauld (2000), Ruìz-Cancino et al. (2010)

von Mérey et al. (2012)

von Mérey et al. (2011)

Castro et al. (2009)

Fernandez and Clavijo (1984), Figueiredo et al. (2006b), Penagos et al. (2005)

Cruz et al. (1997), Figueiredo et al. (2009)

Ashley (1983), Giraldo-Vanegas and Garcia (1992, 1994b, 1995), Lopez et al. (2002), Yaseen et al. (1981)

Some references contribute to multiple topics/classifications

${ }^{a}$ Access to these sources was not available; they are all cited in Molina-Ochoa et al. (2003)

and Ravelo (2007). After the publications of these reviews, Onody et al. (2009) and Melo et al. (2012) both described a new species from Brazil.
Although the genus Eiphosoma is easy to identify, it is difficult to distinguish species from each other (Gauld 2000). Townes and Townes (1966) synonymized E. 
laphygmae with E. vitticolle. Nevertheless, Gauld (2000) resurrected E. laphygmae from this synonymity, mainly because of different rearing records but also because of minor morphological and colour differences. Within their group, the completely yellow mesopleuron mainly distinguishes E. vitticolle from E. laphygmae, which has black marks on the mesopleuron (Gauld 2000). Gauld (2000) stated that all specimens, which have been reared from Spodoptera larvae, are E. laphygmae, not $E$. vitticolle. The host of $E$. vitticolle is unknown (Gauld 2000). However, many of the works cited in this paper were written during the period when the two species were synonymized.

\section{Distribution and habitat}

Eiphosoma laphygmae is widely distributed in the American neotropics, from Sao Paulo in southern Brazil (Melo et al. 2012; Onody et al. 2012; Patel and Habib 1986) to Tamaulipas, northern Mexico (Ruíz-Cancino et al. 2010; Gauld 2000; Pair et al. 1986) (Figs. 2, 3). It is also present in the Caribbean, from Cuba to Trinidad (Gauld 2000; Fernandez-Triana and Ravelo 2007).

Eiphosoma spp. are known to live in lowlands (below $1500 \mathrm{~m}$ ), open and degraded habitats (Fernandez-Triana and Ravelo 2007). They tend to prefer open forests, fields
Fig. 2 Countries from which $E$. laphygmae has been reported with sources $(n=40)$
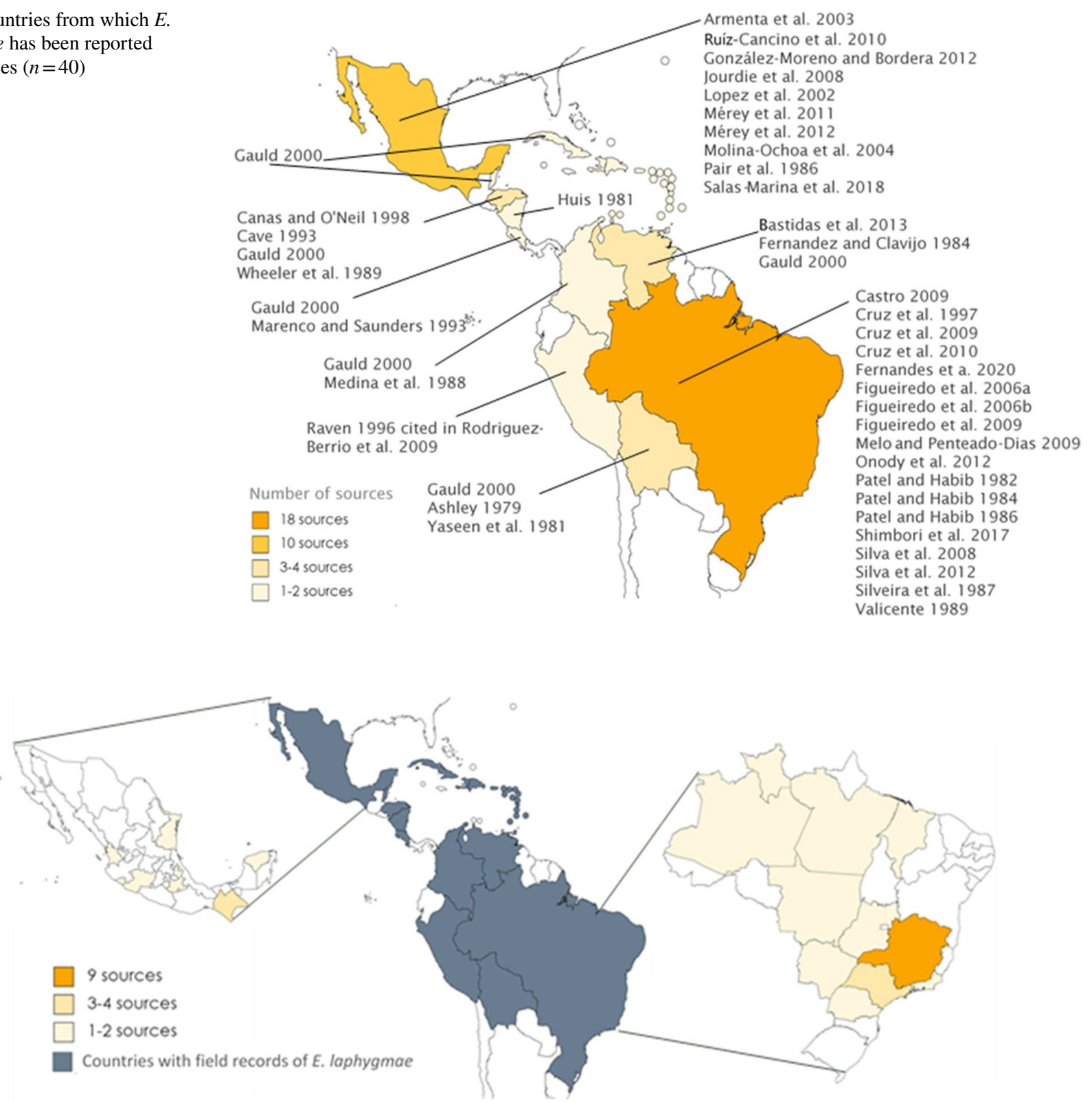

Fig. 3 Field observations of E. laphygmae at the state level in Mexico $(n=10)$ and Brazil $(n=18)$. See Fig. 2 for references 
and sunny habitats (Porter 1983). Eiphosoma spp. are most diverse in the semi-deciduous mesophilic forest, followed by the Amazonian forest and the Cerrado (Melo and PenteadoDias 2009). Onody et al. (2012) observed populations of Eiphosoma spp. in different organic gardens and stated that the management had a greater influence on them than climatic variables. Cortez and Trujillo (1994) tested the effect of three different agroecosystems on the natural enemies of FAW. The occurrence of control agents was higher in more diversified systems; this result is also supported by other authors (Cortez and Trujillo 1994; Molina-Ochoa et al. 2004; Onody et al. 2012). Cortez-Madrigal (1998) found that E. laphygmae was the predominant species in maize fields with weeds, while Chelonus. insularis (Cresson, 1865) (Hymenoptera: Braconidae) dominated in maize without weeds.

\section{Biology and behaviour}

Upon emergence, adults search for food by continuously moving their antennae perpendicularly, in a type of 'drumming' movement, rapidly opening their antennae to search for food (Giraldo-Vanegas and Garcia 1994a). In the laboratory, adults can be fed with honey and maize pollen (GiraldoVanegas and Garcia 1995). Upon finding food, E. laphygmae positions its body horizontally and straightens the antennae in a $45^{\circ}$ angle from the body (Giraldo-Vanegas and Garcia 1994a). Eiphosoma laphygmae does not feed on the body fluids of the host as many other parasitoids do (GiraldoVanegas and Garcia 1994a). Adults can mate immediately after emergence, and females have even been observed to allow multiple copulations on the day of emergence so there is no pre-mating period (Giraldo-Vanegas and Garcia 1994a). This creates a competitive advantage as females become fertile quickly (Giraldo-Vanegas and Garcia 1994a).

López et al. (2002) reported that reproduction begins 6-8 days after emergence at $24.5^{\circ} \mathrm{C}$, while Giraldo-Vanegas and Garcia (1995) observed, at the same temperature, a preoviposition period of 1.6-3.5 days, depending on the available food (Table 3). To locate the host, a female follows the 'track' left behind by FAW-larvae by 'drumming' with her antennae. From the authors' description, it is unclear what is creating this 'track' for E. laphygmae (e.g. host-silk, hostsalvia, host-frass). When the female has strong stimuli, she bends forward to oviposit. However, if she senses that there is no larva, but rather frass, she straightens up and continues to search (Giraldo-Vanegas and Garcia 1994a). Once a larva is detected, she continues the 'drumming' movement and inserts the ovipositor with preference to the central part of the larvae at the level of the pleura. No paralysis of the host has been observed (Giraldo-Vanegas and Garcia 1994a). In Chiapas, Mexico, in field cage trials, E. laphygmae was most active in the morning between 08:00 and 11:00 $\mathrm{h}$ and in early evening from 16:00 to 18:00 h (López et al. 2002). Ashley (1983) let the species oviposit by exposing $S$. frugiperda larvae on a disk of artificial diet. He reported that $E$. laphygmae preferred to search for FAW-larvae by piercing into depressions, which were cut into the diet beforehand, with their ovipositor.

López et al. (2002) stated that the parasitoid attacked the second, third and fourth FAW instars, while Penagos et al. (2005) reported that it attacked only second and third instars. However, other authors observed that E. laphygmae primarily oviposit on first and second instars (Ashley et al. 1982; Ashley 1983). Data from López et al. (2002) indicated that parasitism rates by E. laphygmae are higher on young maize plants, up to an age of 18 days after emergence, than on older plants. However, the same trial data also revealed that first- and second-instar larvae were more abundant on plants 11-18 days post-emergence, while third- and fourth-instar larvae dominated 25- to 39-day-old maize. Larval density can affect parasitism rates (López et al. 2002). In a field trial, higher larval density increased total parasitism of $S$. frugiperda. However, the higher parasitism levels were mainly due to an increase in the proportion of larvae parasitized by Ch. insularis (López et al. 2002). Due to its behaviour, $E$. laphygmae may receive kairomonal stimulation, and it may have chemoreceptors in the antennae, as they are important in searching for food, mating and oviposition (Giraldo-Vanegas and Garcia 1994a).

Table 3 Mean preoviposition period, oviposition period and daily oviposition rate of E. laphygmae fed with three different sources of food under laboratory conditions. Source: adapted from Giraldo-Vanegas and Garcia (1995)

\begin{tabular}{lcrr}
\hline Food source & Preoviposition $^{\mathrm{c}}$ (days) & Oviposition period $^{\mathrm{d}}$ (days) & Daily oviposition rate $^{\mathrm{e}}$ \\
\hline Water & $3.5^{\mathrm{a}} \pm 1.3$ & $9.8^{\mathrm{b}} \pm 1.5$ & $0.23^{\mathrm{a}} \pm 0.03$ \\
Water + honey & $3.2^{\mathrm{a}, \mathrm{b}} \pm 1.3$ & $14.4^{\mathrm{a}, \mathrm{b}} \pm 3.5$ & $0.57^{\mathrm{b}} \pm 0.18$ \\
Water +honey + pollen & $1.6^{\mathrm{b}} \pm 0.6$ & $17.2^{\mathrm{a}} \pm 4.0$ & $0.83^{\mathrm{b}} \pm 0.19$ \\
\hline
\end{tabular}

${ }^{*}$ The means within each column with the same letter (i.e. a, b) do not differ significantly $(p<0.05)$

${ }^{\mathrm{c}}$ Period before oviposition of the first egg

${ }^{\mathrm{d}}$ Period between oviposition of the first egg until the last egg

${ }^{\mathrm{e}}$ Number of eggs per larvae and day 
Giraldo-Vanegas and Garcia (1995) studied the influence of food on E. laphygmae reproduction. Water, water and honey, and a mixture of water, honey and maize pollen were compared. Daily oviposition rate, preoviposition and oviposition period were significantly different for treatments with honey compared to the treatment with only water (Table 3 ). Since the egg production depends on the nutrition of the adults, it is assumed that E. laphygmae is synovigenic (Flanders 1950; Giraldo-Vanegas and Garcia 1995). Synovigenic females require a source of protein for continuous egg production throughout their adult life (Hagen 1950, 1953).

Spodoptera frugiperda larvae can prevent the development of E. laphygmae through melanization and hemocytic encapsulation of the parasitoid egg (Pérez-Kepp 2007). In choice tests, where some hosts were infected by an invertebrate iridescent virus, oviposition by E. laphygmae was significantly higher on infected larvae (33\%) than on uninfected ones (17\%) (López et al. 2002). Infected larvae were unresponsive to the attacking female. On the contrary, when uninfected larvae were touched by the parasitoid, they waved the upper half of their body actively back and forth at a rate of $1.2 \mathrm{~s}^{-1}$ (López et al. 2002). Infected larvae often died prematurely and so the endoparasitoid did not develop. So E. laphygmae parasitized these infected larvae, although they were unsuitable hosts. This implies a time-limited than an egg-limited reproduction (López et al. 2002). According to the optimal foraging theory (Godfray 1994), egg-limited parasitoids have very high fitness costs when they oviposit on an unsuitable host, but these costs are insignificant for time-limited wasps (Godfray 1994; López et al. 2002). In Lopéz et al.'s experiment, all females that stung an infected host transmitted the virus to subsequently attacked larvae (López et al. 2002). Yet females emerging from infected hosts did not transmit the virus (López et al. 2002).

Ashley (1983) studied growth pattern alterations in FAW after oviposition by different species and found a significantly prolonged duration of the second instar when parasitized by E. laphygmae. Maximum larval weight was reduced by $62 \%$ compared with non-parasitized sixth-instar larvae, and by $17 \%$ for non-parasitized fourth-instar larvae (Ashley 1983). The development of immature E. laphygmae has been studied by Giraldo-Vanegas and Garcia (1992, 1994b). In brief, the life cycle from oviposition to adult emergence lasted, on average, $27.8 \pm 1.5$ days at $24.5^{\circ} \mathrm{C}$ and $70 \% \pm 10 \%$ relative humidity (Giraldo-Vanegas and Garcia 1994b). Eiphosoma laphygmae has four larval instars and a prepupal stage in the cocoon (Giraldo-Vanegas and Garcia 1992) (Table 4).

The female deposits her egg in the haemocele of the host; there it floats freely until it stops at the posterior of the host's body (Giraldo-Vanegas and Garcia 1994b). Two days after oviposition, the first larva hatches, developing slowly during the first nine days and feeding on the
Table 4 Number of observations $(N)$ and duration (mean \pm s.e.) of instars of Eiphosoma laphygmae. Source: Adapted from GiraldoVanegas and Garcia (1994b)

\begin{tabular}{lllc}
\hline Instar $^{\mathrm{a}}$ & Days $^{\mathrm{b}}$ & $N$ & Duration (days) $^{\mathrm{c}}$ \\
\hline Egg & $0-4$ & n.a & $2.06 \pm 1.08$ \\
I & $2-10$ & 84 & $4.49 \pm 2.51$ \\
II & $8-12$ & 43 & $2.84 \pm 1.40$ \\
III & $11-15$ & 37 & $2.89 \pm 1.33$ \\
IV & $13-16$ & 39 & $2.64 \pm 1.11$ \\
V Prepupa & n.a & 23 & $1.12 \pm 0.33$ \\
Pupa & n.a & 36 & $11.81 \pm 0.88$ \\
\hline
\end{tabular}

${ }^{\mathrm{a}}$ Under laboratory conditions $\left(24{ }^{\circ} \mathrm{C}\right.$ and $70 \% \pm 10 \%$ relative humidity)

${ }^{\mathrm{b}}$ Days since oviposition during which the instars were observed

${ }^{\mathrm{c}}$ Mean duration of the instar under laboratory conditions with standard deviation

haemolymph by cuticular absorption (Giraldo-Vanegas and Garcia 1994b). Since the larva initially does not consume any vital organs, the host develops normally in the early instars (Giraldo-Vanegas and Garcia 1994b). The larva moves within the haemocele of its host to its caudal appendage up to the level of the Malpighian tubules (Giraldo-Vanegas and Garcia 1994b). The loss of the cephalic capsule differentiates the second instar from the first; here, the larvae possibly begin to feed on sources other than the haemolymph (Giraldo-Vanegas and Garcia 1994b). Growth rate increases noticeably from the 10th to 13th day after parasitism, hampering host development, and the larvae feeds on adipose tissue and, then, later all organs of the host except for the integument. One to two days before emergence the host drills into the soil or any other substrate and goes into a prepupal stage, in which it also prepares its pupal cell. Before emerging, the larva is in reverse position in the host, with its head capsule pointing towards the posterior end of the host (Giraldo-Vanegas and Garcia 1994b). The FAW is in its fifth instar when $E$. laphygmae emerges (Ashley 1983; Marenco and Saunders 1993; Penagos et al. 2005; Wheeler et al. 1989). Once emerged, the larva immediately begins to weave a silk cocoon (Giraldo-Vanegas and Garcia 1994b). At $24.5^{\circ} \mathrm{C}$, the fourth instar was observed for 13-16 days after parasitism (Giraldo-Vanegas and Garcia 1994b). López et al. (2002) observed that E. laphygmae emerged from the host 12 days after parasitism at $26{ }^{\circ} \mathrm{C}$, so development rate increased with higher temperature. Once in the cocoon, the prepupal stage lasts one day (Giraldo-Vanegas and Garcia 1994b). At $26^{\circ} \mathrm{C}$, the pupal stage lasts 12 days for males and 13 days for females (López et al. 2002). The emerging adult breaks the cocoon with its jaws then rests, hardens the cuticula, spreads its wings, cleans its body and searches for food (Giraldo-Vanegas and Garcia 1994b). 


\section{Specificity of E. laphygmae}

Based on the reviewed literature, E. laphygmae seems to be highly specific to $S$. frugiperda in the Americas. However, Gauld (2000) mentioned one specimen of E. laphygmae as a parasitoid of Alabama argillacea (Hübner), the cotton leafworm, in Venezuela. The specimen was found at the United States National Museum of Natural History and had been collected by Clavijo and Ribot in 1970. Ruíz-Cancino et al. (2010) also mention Alabama argillacea as a host of the parasitoid. However, the authors cited Gauld (2000), and it is unclear whether they refer to the same specimen as Gauld (2000) or another one. The cotton leafworm, once the most important cotton pest, which was native to the Americas, apparently became extinct by the end of the twentieth century (Wagner 2009). Additionally, Anticarsia gemmatalis was reported as a host of E. laphygmae in Honduras (Cave 1993). It is unclear how many parasitized specimens were found, and on which crop they were collected. Eiphosoma laphygmae has never been reported as a parasitoid of $A$. argillacea and A. gemmatalis in field studies, although $A$. gemmatalis is an important pest of soybean (Knaak and Fiuza 2005). It is possible that the host species were misidentified or mixed up during rearing.

\section{Eiphosoma laphygmae parasitism rates and population dynamics}

On average, E. laphygmae parasitized 4.5\% $(n=19)$ of the FAW in the fields in the Americas, the median being lower $(3.1 \%)(n=19)$ (Table 5). Parasitism rates by E. laphygmae in the field were highly variable between different sites (Fig. 4), ranging from $0.7 \%$ of all collected FAW larvae in Sao Paulo, Brazil (Patel and Habib 1986), to $14.5 \%$ in Minas Gerais (Brazil) (Cruz et al. 2010). Sampling technique was similar for 14 locations, whereby larvae were collected from the plants and reared under controlled conditions. Only in Honduras were plants cut and dissected for larvae (Wheeler et al. 1989). However, the season of data collection can influence parasitism rates. von Mérey et al. (2012) reported much higher parasitism rates by E. laphygmae in the second cropping season than in the first one in Mexico but does not quantify it. Only three out of the 15 reviewed studies collected data in a second cropping season (Cruz et al. 2010; Marenco and Saunders 1993; von Mérey et al. 2011), yet these reported highest parasitism rates of all reviewed locations $(14.5 \%, 13.0 \%$ and $6.7 \%$ respectively). In Brazil, in the state Minas Gerais the mean parasitism rate of E. laphygmae in the first cropping season was $2.7 \%(n=6)$, while Cruz et al. (2010) found $14.5 \%$ in the second cropping season. In Honduras, E. laphygmae was most abundant from July to September on maize (first cropping season) but was most abundant on sorghum in the second cropping season (unpublished data, Cave 1993). The contribution of the species to total parasitism varies also greatly between sites. In the same year E. laphygmae's contribution to total parasitism was $100 \%$ in Tejabán (Mexico) and 3.3\% in Los Mezcales (Mexico) (Molina-Ochoa et al. 2004). Chelonus insularis was the dominant parasitoid in 15 of 25 sites where E. laphygmae was observed (Fig. 5) and was responsible for $48 \%$ of total parasitism of the three most dominant species. Ch. insularis was followed by E. laphygmae, the most dominant parasitoid in 4 out of 25 locations and contributing $27 \%$ to total parasitism of the three most dominant species (Fig. 6). Other parasitoids contributing significantly to total parasitism were Campoletis flavincincta (Ashmead) and Pristomerus spinator (Fabricius). Marenco and Saunders (1993) observed that high parasitism by E. laphygmae coincided with low levels of Pristomerus spinator, implying that the two parasitoids are in competition. Other natural enemies were: Meteorus sp., Archytas marmoratus (Townsend), Archytas incertus (Macquart), Lespesia sp., Lespesia lanei (Guimaraes), Ophion flavidus (Brullé), Hexamermis sp., Exasticolus fusciornis (Cameron) and Chelonus cautus (Cresson).

\section{Pest management impacts}

von Mérey et al. (2012) assessed the impact of plant growth regulators on E. laphygmae; however, no impact was found (von Mérey et al. 2012). von Mérey et al. (2011) assessed the effect of green leaf volatiles on parasitism rates of $S$. frugiperda; no effect was found for E. laphygmae (von Mérey et al. 2011). Castro et al. (2009) compared the impact of conventional versus genetically modified Bacillus thuringiensis maize (Bt-maize) on natural enemies of $S$. frugiperda. There were fewer FAW-larvae on Bt-maize, but only in the first 15 days after plant emergence, which seemed to be related to a higher number of natural enemies, including E. laphygmae, in conventional fields, but it is unclear whether this difference was significant (Castro et al. 2009).

There have been few studies on the effect of insecticides on E. laphygmae. In a field trial testing the effect of the organophosphate pesticide chlorpyrifos on natural enemies of the FAW, E. laphygmae accounted for $12.3 \%$ of larval mortality before spraying. After spraying, the insecticide was responsible for $97.54 \%$ larval mortality, whereas $E$. laphygmae was accounted for $0.25 \%$ larval mortality (Figueiredo et al. 2006b). Fernandez and Clavijo (1984) observed that the natural enemy population, including E. laphygmae, were significantly lower using diazinon, a non-systemic organophosphate insecticide, than when using Thuricide, containing $B$. thuringiensis var. kurstaki. Figueiredo et al. (2009) assessed natural enemy population before and after spraying Baculovirus spodoptera, a nuclear polyhedrosis virus. The contribution of E. laphygmae to larval mortality 


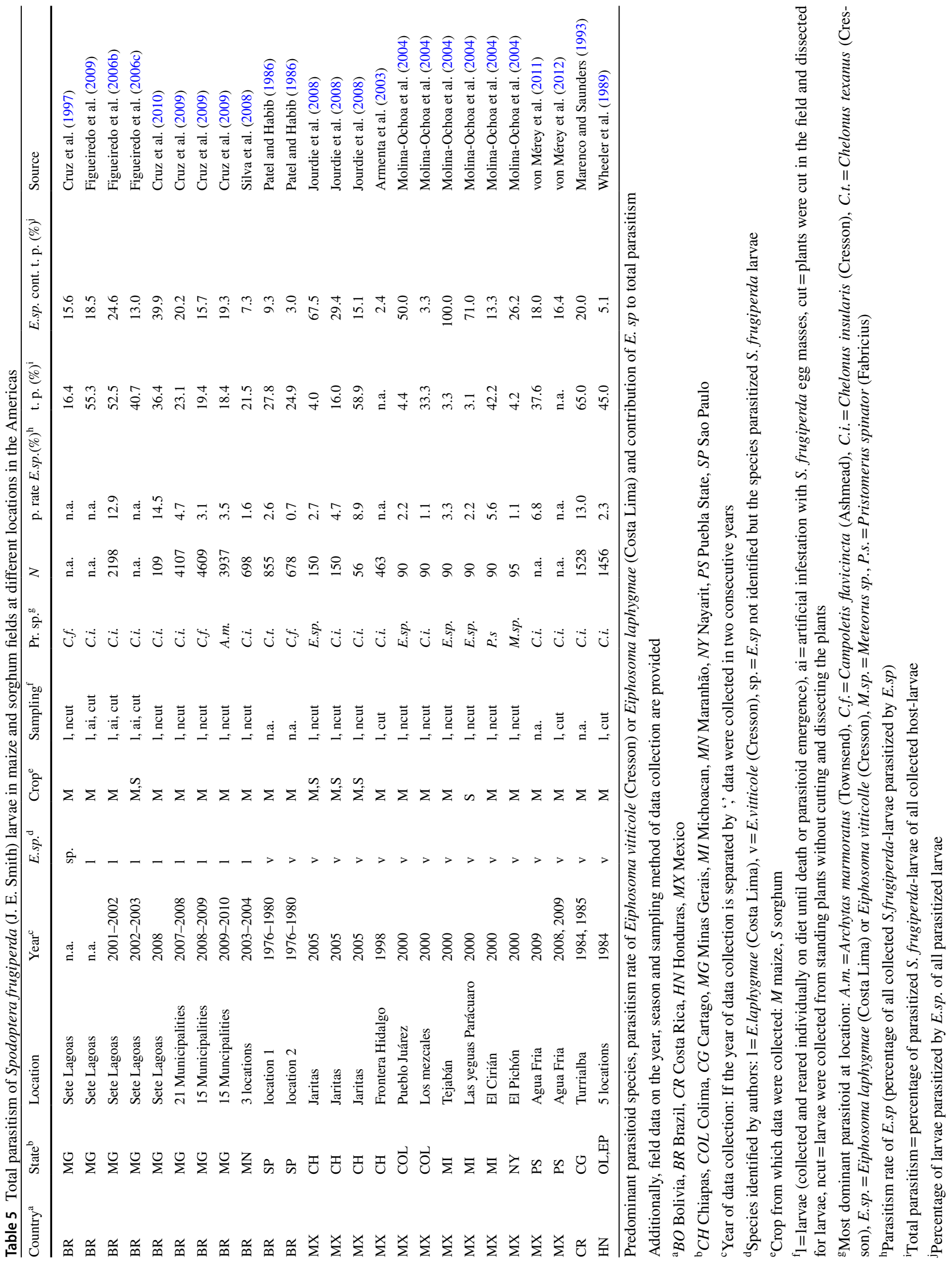




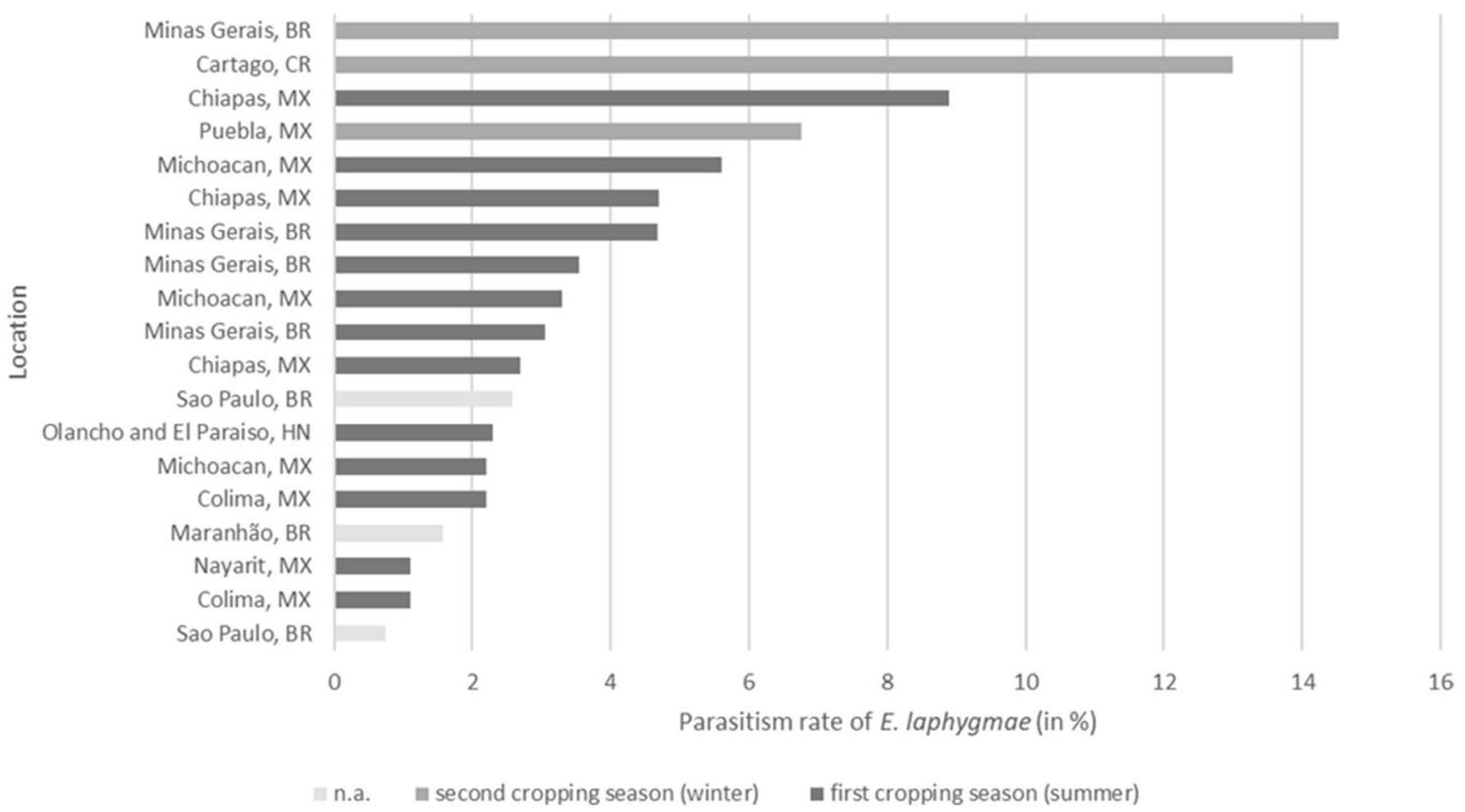

Fig. 4 Total parasitism of $S$. frugiperda and parasitism rate of $E$. laphgymae at different locations in the Americas. BR Brazil, $C R$ Costa Rica, $H N$ Honduras, $M X$ Mexico. References: Cruz et al.

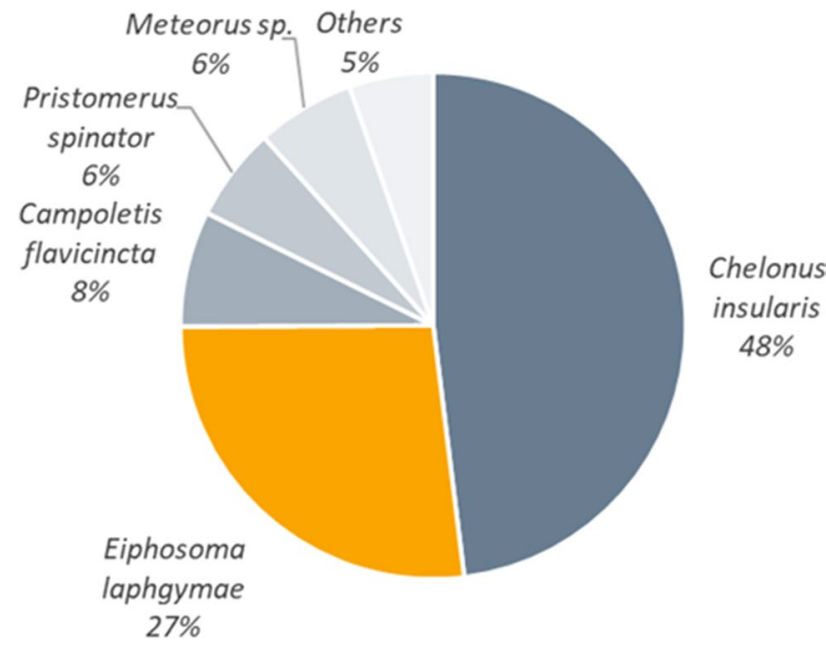

Fig. 5 Mean contribution of different parasitoids of Spodoptera frugiperda (J.E. Smith) to total parasitism of the three most dominant species in fields where Eiphosoma laphygmae (Costa Lima) or Eiphosoma vitticole (Cresson) have been observed ( $n=25$ different locations throughout the Americas). References: Armenta et al. (2003), Cruz et al. (1997, 2009, 2010), Figueiredo et al. (2006b, c, 2009), Jourdie et al. (2008), Marenco and Saunders (1993), Meréy et al. (2011, 2012), Molina-Ochoa et al. (2004), Patel and Habib (1986), Silva et al. (2008), Wheeler et al. (1989)

before spraying was $18.5 \%$ and after spraying $8.5 \%$, while the virus was responsible for $50 \%$ of the mortality at the highest dosage of application (1000 larval equivalents of
(2009, 2010), Marenco and Saunders (1993), Jourdie et al. (2008), von Mérey et al. 2011, Molina-Ochoa et al. (2004), Patel and Habib (1986), Wheeler et al. (1989), Silva et al. (2008)

virus/ha). Cruz et al. (1997) also showed that the mortality caused by parasitoids was lower with increasing dosage of nuclear polyhedrosis virus. In a laboratory experiment E. laphygmae also parasitized larvae, which were treated externally with 200 ppm Spinosad, even though the endoparasitoid could not develop, since all host-larvae died as a result of the applied insecticide (Penagos et al. 2005).

\section{Previous attempts at rearing and releasing $E$. laphygmae}

Little information is available on rearing E. laphygmae in the laboratory. Ashley (1983) let E. laphygmae oviposit on disks of diet with 0.5 -cm-deep depressions. The disks were supported by a piece of hardware cloth and put in the centre of a plexiglass cylinder. The authors let around 100 newly hatched larvae enter into the depressions, before the parasitoids were put in the cage for $48 \mathrm{~h}$, temperature was at $28^{\circ} \mathrm{C}$. López et al. (2002) exposed third-instar larvae for choice tests, and Giraldo-Vanegas and Garcia (1992, 1994b, 1995) exposed around 150 six-day-old larvae to oviposition; both authors worked at $24.5{ }^{\circ} \mathrm{C}$. Lòpez et al. (2002) report that adding some FAW frass facilitated oviposition.

One thousand pairs of E. laphygmae originating from Bolivia were released in Florida as classical biological control agents since the parasitoid does not occur naturally in USA (Ashley et al. 1982). However, it was unsuccessful (Ashley et al. 1982; Meagher et al. 2016), possibly because 
Fig. 6 Frequency of the predominant parasitoid of Spodoptera frugiperda (J.E. Smith) and second and third most abundant species in field observations where Eiphosoma laphygmae (Costa Lima) or Eiphosoma vitticole (Cresson) occurred

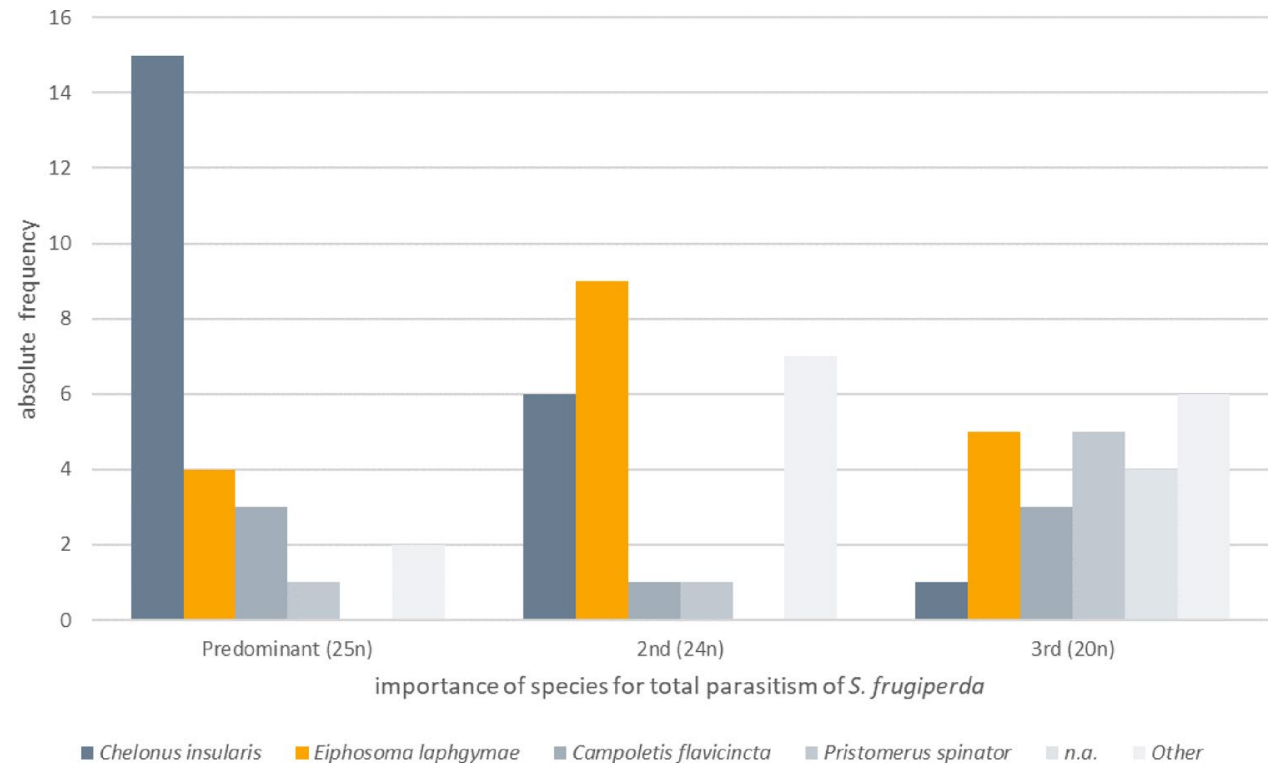

the native parasitoids preferred to attack the same instars as E. laphygmae (Ashley et al. 1982). Yaseen et al. (1981) introduced E. laphygmae from Bolivia in Trinidad, but also reported the presence of the species prior to the introduction at the same location.

\section{Discussion}

Based on this review, E. laphygmae can be considered as a promising biological control agent against FAW in Africa and Asia because of its importance in the parasitoid complex of FAW in its native range, its apparent specificity and the lack of congeneric species in Africa and Asia.

Much information on the biology of E. laphygmae is already available. However, many knowledge gaps remain. In particular, its specificity needs to be better assessed and efficient laboratory rearing methods need to be developed before E. laphygmae can be introduced as classical biocontrol agent. Currently, classical biological control must include a proper assessment of the potential risk posed by the introduction of the agent, in particular on non-target hosts or prey (Hajek et al. 2016). Various protocols for specificity tests are available (e.g. Van Driesche and Reardon 2004), and analyses of previous introductions of classical biocontrol agents show that such natural enemies rarely become problematic when proper testing is done (Barratt 2011; Hokkanen et al. 2003; Myers and Cory 2017; van Driesche et al. 2010; van Driesche and Hoddle 2016). Concerns have been raised about potential non-target effects of classical biocontrol agents (e.g. Howarth 1991). However, Lynch and Thomas (2000) analysed 5000 cases of parasitoid or predator introductions and concluded that non-target effects have been recorded in only $1.7 \%$ of cases and the majority of these only caused minor effects. Van Driesche et al. (2010) showed that of 21 reviewed insect biocontrol programmes, $84 \%$ of introductions had positive effects on biodiversity, $5 \%$ had positive effects on ecosystems services, and $48 \%$ increased product harvesting from natural systems.

However, any candidate needs to fulfil the "Guidelines for the export, shipment, import and release of biological control agents and other beneficial organisms" before a release in Africa (FAO and IPPC 2016) and country-specific requirements. Specificity tests for E. laphygmae should include closely related African and Asian Noctuids, such as other Spodoptera species. Also, studies should focus on laboratory rearing methods to ensure that sufficient adults are available for releases at the continental scale. First trials showed that laboratory cultures are hampered by low parasitism rates and strongly male-biased sex ratio (T. Allen and M. Kenis, unpublished data). Factors affecting parasitism success and sex ratio in laboratory rearing should be better investigated.

In its native range, E. laphygmae is confined to the tropical areas and has been rarely reported in the subtropics. Eiphosoma laphygmae is apparently absent from USA and Argentina (e.g. Pair et al. 1986; Murúa et al. 2009; HayRoe et al. 2016; Meagher et al. 2016). In Mexico, there are several studies either without any record of the species (e.g. Vírgen et al. 2013; Hoballah et al. 2004; Ordóñez-García et al. 2015) or where E. laphygmae was observed only in few sampled locations (Jourdie et al. 2008; Molina-Ochoa et al. 2004), possibly because these were situated in cooler, mountainous regions. This implies that while E. laphygmae might be effective as a biocontrol agent within tropical zones of the invasive range of FAW, it might be less suitable in subtropical zones of China, most of South Africa and invaded mountain areas such as in East Africa and the Himalayas. If $E$. 
laphygmae is deemed a suitable biological control agent for FAW, it would be recommended to use strains from locations climate-matched to the target area (Hoelmer and Kirk 2005).

In South America north of Argentina, E. laphygmae has been found in nearly all studies on the parasitoid complex of FAW and it is usually considered as being one of the three main species of the complex, as shown in our review. In fields where E. laphygmae occurred, based on the three most frequent species, Ch. insularis contributed $47 \%$ to total parasitism and E. laphygmae to 27\%. Chelonus insularis has the largest natural distribution of all FAW parasitoids in the Americas, and it is, at the continental scale, the most important parasitoid of FAW in its native region (Molina-Ochoa et al. 2003). However, it is considered less specific than $E$. laphygmae, being recorded from several other Lepidoptera (Yu et al. 2005), and several other Chelonus spp. are among the main parasitoids of FAW in Africa and Asia (Agboyi et al. 2020; Gupta et al. 2020; Durocher-Granger et al. 2021). Thus, compared to E. laphygmae, the introduction of $C h$. insularis in Africa or Asia would involve a higher risk of undesirable effects on non-target hosts and of competition with native parasitoids.

In general, larval parasitism rates mentioned in the literature are low from Latin America. We found mean parasitism by E. laphygmae to be $4.3 \%$ with up to $15 \%$ reported, and only Ch. insularis sometimes showed higher parasitism. However, the parasitism rates found in the literature are most likely largely underestimated. As with most hymenopteran larval parasitoids of FAW, E. laphygmae parasitizes the smaller, early FAW instars (Ashley et al. 1982; Ashley 1983; López et al. 2002; Penagos et al. 2005) and kills it in its fifth instar (Ashley 1983; Marenco and Saunders 1993; Penagos et al. 2005; Wheeler et al. 1989). Thus, sampling including larger larvae would underestimate the mean parasitism across larval stages. Small $S$. frugiperda larvae are often hidden in the plant whorl (FAO 2018b), so these parasitized larvae are less likely to be sampled. Furthermore, parasitized larvae grow and eat much less (Ashley 1983), causing much less damage than healthy larvae, the latter being much more obvious in the field. In addition, studies usually calculate parasitism by dividing the number of parasitoids divided by the number of larvae collected. However, parasitized larvae, especially those parasitized by E. laphygmae, are much more likely to die in the laboratory before maturation than healthy larvae, which, again, leads to an underestimation of parasitism rates (Jourdie et al. 2008; von Mérey et al. 2011).

Agricultural management practices, such as spraying insecticides and herbicides, can impact parasitism rates by E. laphygmae and other parasitoids substantially (CortezMadrigal 1998; Figueiredo et al. 2006b). In the Americas, most maize fields are either sprayed with chemical insecticides or planted with GM maize. The latter also affects parasitoid populations because FAW parasitoids are strongly host-density-dependent (Durocher-Granger et al. 2021). Area-wide control of FAW and other crop pests has a strong negative long term effect on parasitoids and, therefore, in such environments it is not surprising that field parasitism assessments, even when conducted on unsprayed, non-GM maize varieties, will provide low parasitism rates.

More generally, biological control needs to be adapted to the regional level, since dominance of parasitoid species varies greatly between different locations even within the same state (Silva et al. 2008; Cruz et al. 2009). Differences in agroecosystems can explain such variation in nearby localities (Silva et al. 2008). Onody et al. (2012) have shown that the differences in prevalence of Eiphosoma spp. depend more on crop management than on climatic variation within a region. We observed a tendency that E. laphygmae established better in more diverse systems. The species has only been found in two of 12 locations in Sao Paulo by Patel and Habib (1986) but in all three organic gardens in Sao Paulo (Onody et al. 2012). Also, Cortez-Madrigal (1998) observed that E. laphygmae predominated in weedy maize fields, while $C h$. insularis predominated in weeded ones. E. laphygmae is assumed to be synovigenic (Giraldo-Vanegas and Garcia 1995), producing eggs throughout the adult stage by relying on continuing nutrition, so weed flowers serve as an important source of food (Syme 1975) and vegetation rich in nectar and pollen can facilitate establishment (Leius 1963). In tropical Africa, agroecosystems tend to be more diverse than in the Americas, as much more mixed cropping is practiced (Kenis et al. 2019). Before the arrival of FAW, insecticide use by smallholder farmers in Africa was relatively low (Sheahan and Barrett 2017). This situation potentially favours E. laphygmae establishment as a classical biological control agent.

Supplementary Information The online version contains supplementary material available at https://doi.org/10.1007/s41348-021-00480-9.

Acknowledgements We thank two anonymous reviewers for their helpful suggestions which improved an earlier version of this manuscript.

Funding Open Access funding provided by Berner Fachhochschule BFH. MK was financially supported by the Foreign, Commonwealth and Development Office (FCDO), UK, and the Directorate-General for International Cooperation (DGIS), Netherlands, through CABI's Action on Invasives programme.

Data availability We list the publications used in annex.

\section{Declarations}

Conflict of interest The authors have no conflicts of interest to declare that are relevant to the content of this article. 
Open Access This article is licensed under a Creative Commons Attribution 4.0 International License, which permits use, sharing, adaptation, distribution and reproduction in any medium or format, as long as you give appropriate credit to the original author(s) and the source, provide a link to the Creative Commons licence, and indicate if changes were made. The images or other third party material in this article are included in the article's Creative Commons licence, unless indicated otherwise in a credit line to the material. If material is not included in the article's Creative Commons licence and your intended use is not permitted by statutory regulation or exceeds the permitted use, you will need to obtain permission directly from the copyright holder. To view a copy of this licence, visit http://creativecommons.org/licenses/by/4.0/.

\section{References}

Agboyi LK, Goergen G, Beseh P, Mensah SA, Clottey VA, Glikpo R, Buddie A, Cafà G, Offord L, Day R, Rwomushana I, Kenis M (2020) Parasitoid complex of fall armyworm, Spodoptera frugiperda in Ghana and Benin. Insects 11:68

Allen E, Valdez C (2016) Brazil's corn industry and the effect on the seasonal pattern of U.S. corn exports: electronic outlook report from the economic research service 2016 No.AES-93, p 19

Armenta R, Martínez AM, Chapman JW, Magallanes R, Goulson D, Caballero P, Cave RD, Cis-neros J, Valle J, Castillejos V, Penagos DI, García LF, Williams T (2003) Impact of a nucleopolyhedrovirus bioinsecticide and selected synthetic insecticides on the abundance of insect natural enemies on maize in southern Mexico. J Econ Entomol 96:649-661. https://doi.org/10.1093/ jee/96.3.649

Ashley TR (1979) Classification and distribution of fall armyworm parasites. Fla Entomol 62:114. https://doi.org/10.2307/3494087

Ashley TR (1983) Growth pattern alterations in fall armyworm, Spodoptera frugiperda, larvae after parasitization by Apanteles marginiventris, Campoletis grioti, Chelonus insularis, and Eiphosoma vitticole. Fla Entomol 66:260. https://doi.org/10.2307/ 3494250

Ashley TR, Waddill VH, Mitchell ER, Rye J (1982) Impact of native parasites on the fall armyworm, Spodoptera frugiperda (Lepidoptera: Noctuidae), in South Florida and release of the exotic parasite, Eiphosoma vitticole (Hymenoptera: Ichneumonidae). Environ Entomol 11:833-837. https://doi.org/10.1093/ee/11.4. 833

Barratt BIP (2011) Assessing safety of biological control introductions. CAB Rev. https://doi.org/10.1079/PAVSNNR20116042

Bastidas L, Chacón B, Amesty Y, González F (2013) Entomofauna asociada al cultivo de maíz blanco var. Turen 2000 en la planicie de Maracaibo, Venezuela. In: Resumenes del XXIII Congreso Venezolano de Entomología, vol 28. Entomotropica, p 133

CABI (2021). Spodoptera frugiperda. In: Invasive species compendium. CAB International, Wallingford, UK. www.cabi.org/isc

Castro ALG, Cruz I, Silva IF, Paula CDS (2009) Flutuação populacional do parasitóide Eiphosoma vitticole (Cresson) (Hymenoptera: Ichneumonidae). In: Congresso Brasileiro de Agroeco-logia (ed) Agricultura familiar e camponesa experiências passadas e presentes construindo um futuro sustentáve, pp 4978-4982

Canas LA, O'Neil RJ (1998) Applications of sugar solutions to maize, and the impact of natural enemies on fall armyworm. Int J Pest Manag 44:59-64. https://doi.org/10.1080/096708798228329

Cave RD (1993) Parasitoides larvales y pupales de Spodoptera frugiperda (Smith) (Lepidoptera: Noctuidae) en Centro América con una clave para las especies encontradas en Honduras. Cei-Ba 34:33-56

Cockerell TDA (1913) New parasitic Hymenoptera of the genus Eiphosoma. Proc US Natl Mus 46:61-64
Cortez MH, Trujillo AJ (1994) Incidencia del gusano cogollero y sus enemigos naturales en tres agrosistemas de maiz. Turrialba 44:1-9

Cortez-Madrigal H (1998) Impacto de malezas en el biocontrol de Spodoptera frugiperda (Lep: Noctuidae) en maiz. Revista Chapingo Serie Ingenieria Agropecuaria 1:19-23

Costa Lima A (1953) Espécies de Eiphosoma Cresson (Hymenoptera, Ichneumonidae, Ophioninae). Arquivos Do Museu Nacional 42:175-189

Cruz I, Oliveira LJ, Oliveira AC, Carlos AV (1996) Efeito do nível de saturação de alumínio em solo àcido sobre os danos de Spodoptera frugiperda (J. E. Smith) em milho. An Soc Entomol Bras 25:293-297

Cruz I, Figueiredo MLC, Valicente FH, Oliveira AC (1997) Application rate trials with a nuclear polyhedrosis virus to control Spodoptera frugiperda (Smith) on maize. An Soc Entomol Brasil 26:145-152. https://doi.org/10.1590/S0301-80591997000100019

Cruz I, Figureido M, Silva RB, Del Sarto M, Penteado-Dias A (2009) Monitoramento de parasitoides de lagartas de Spodoptera frugiperda (JE Smith) (Lepidoptera: Noctuidae) em municípios de Minas Gerais, Brasil. Documentos 92, Embrapa, Milho e Sorgo. Sete Lagoas, Brazil, p 92

Cruz I, Figueiredo MLC, Silva RB, Foster JE (2010) Efficiency of chemical pesticides to control Spodoptera frugiperda and validation of pheromone trap as a pest management tool in maize crop. Revista Brasileira De Milho e Sorgo 9:107-122. https://doi.org/ 10.18512/1980-6477/rbms.v9n2p107-122

Day R, Abrahams P, Bateman M, Beale T, Clottey V, Cock M, Colmenarez Y, Corniani N, Early R, Godwin J, Gomez J, Gonzalez Moreno P, Murphy ST, Oppong-Mensah B, Phiri N, Pratt C, Richards G, Silvestri S, Witt A (2017) Fall armyworm: impacts and implications for Africa: Evidence Note (2), September 2017. https://www.invasive-species.org/wp-content/uploads/sites/2/ 2019/03/Fall-Armyworm-Evidence-Note-September-2017.pdf. Accessed 31 May 2019

Durocher-Granger L, Mfune T, Musesha M, Lowry A, Reynolds K, Buddie A, Cafà G, Offord L, Chipabika G, Dicke M, Kenis M (2021) Factors influencing the occurrence of fall armyworm parasitoids in Zambia. J Pest Sci. https://doi.org/10.1007/ s10340-020-01320-9

FAO (2018a) Reduction of human health and environmental risks of pesticides used for control of fall armyworm: FAW Guidance Note1, p 4. http://www.fao.org/3/I8320EN/i8320en.pdf. Accessed 31 Dec 2019

FAO (2018b) Integrated management of the fall armyworm on maize. A guide for farmer field schools in Africa. FAO, Rome, Italy, p 127

FAO (2019) Country briefs. http://www.fao.org/giews/countrybrief/ index.jsp. Accessed 21 Dec 2019

FAO and IPPC (2016) ISPM3: guidelines for the export, shipment,import and release of biological control agents and other beneficial organisms. http://www.fao.org/3/j5365e/j5365e. pdf

Feldmann F, Rieckmann U, Winter S (2019) The spread of the fall armyworm Spodoptera frugi-perda in Africa-what should be done next? J Plant Dis Prot 126:97-101. https://doi.org/10.1007/ s41348-019-00204-0

Fernandez BRI, Clavijo AS (1984) Efectos de dos insecticidas (uno quimico y otro biologico) sobre el parasitismo observado en larvas de Spodoptera frugiperda (S.) provenientes de parcelas experimentales de maiz. Revista De La Facultad De Agronomia 13:101-109

Fernandes DRR, Rogéria LIR, Perioto NW (2020) New records of Ichneumonidae (Hymenoptera: Ichneumonoidea) from a coffee agroecosystem of southeastern Brazil. Entomol Commun 2:ec02031. https://doi.org/10.37486/2675-1305.ec02031 
Fernandez-Triana JL, Ravelo HG (2007) A taxonomic review of Cuban Eiphosoma Cresson (Hy-menoptera: Ichneumonidae), with biogeographical notes. Zootaxa 1655:49-61. https://doi.org/10. 11646/ZOOTAXA.1655.1.2

Figueiredo MDLC, Martins-Dias AMP, Cruz I (2006a) Relação entre a lagarta-do-cartucho e seus agentes de controle biológico natural na produção de milho. J Econ Entomol 41:1693-1698. https:// doi.org/10.1590/S0100-204X2006001200002

Figueiredo MLC, Dias AMPM, Cruz I (2006b) Efeito do inseticida chlorpyrifos e sua interação com inimigos naturais na supressão de Spodoptera frugiperda (J.E. Smith, 1797) (Lepidoptera: Noctuidae) na cultura do milho. Revista Brasileira De Milho e Sorgo 5:325-339. https://doi.org/10.18512/1980-6477/rbms. v5n3p325-339

Figueiredo MLC, Dias AMPM, Cruz I (2006c) Associação entre inimigos naturais e Spodoptera frugiperda (J.E. Smith, 1797) (Lepidoptera: Noctuidae) na cultura do milho. Revista Brasileira De Milho e Sorgo 5:340-350. https://doi.org/10.18512/1980-6477/ rbms.v5n3p340-350

Figueiredo MLC, Cruz I, Penteado-Dias AM, Silva RBD (2009) Interaction between Baculovirus spodoptera and natural enemies on the suppression of Spodoptera frugiperda (J. E. Smith) (Lepidoptera: Noctuidae) in maize. Revista Brasileira De Milho e Sorgo 8:207-222. https://doi.org/10.18512/1980-6477/rbms. v8n3p207-222

Flanders SE (1950) Regulation of ovulation and egg disposal in the parasitic Hymenoptera. Can Entomol 82:134-140. https://doi. org/10.4039/Ent82134-6

Gauld ID (2000) The Ichneumonidae of Costa Rica, 3rd edn, vol 63. Memoirs of the American Entomological Institute

Giraldo-Vanegas H, Garcia RJL (1992) Determinaction del numero de instares de Eiphosoma vit-ticole Cresson (Hymneoptera: Ichneumonidae). Bol Entomol Venenz 7:133-137

Giraldo-Vanegas H, Garcia RJL (1994a) Comportamiento, descripcion y tiempo de desarrollo de los estados inmadurosde Eiphosoma vitticolle Cresson (Hymenoptera: Ichneumonidae), para-sito de Spodoptera frugiperda (J. E. Smith) (Lepidoptera: Noctuidae). Agron Trop (maracay) 4:645-665

Giraldo-Vanegas H, Garcia RJL (1994b) Comportamiento de los adultos de Eiphosoma vitticole Cresson (Hymenoptera: Ichneumonidae), parasito de Spodoptera frugiperda (Smith) (Lepidoptera: Noctuidae). Bol Entomol Venenz 9:15-20

Giraldo-Vanegas H, Garcia RJL (1995) Influencia de la alimentacion sobre la capacidad reproductiva de Eiphosoma vitticolle Cresson (Hymenoptera: Ichneumonidae), parasito de Spodoptera frugiperda (J. E. Smith). Agron Trop (maracay) 45:159-170

Godfray HCJ (1994) Parasitoids: behavioral and evolutionary ecology. Monographs in behavior and ecology. Princeton University Press, Princeton, p 473

Goergen G, Kumar PL, Sankung SB, Togola A, Tamò M (2016) First report of outbreaks of the fall armyworm Spodoptera frugiperda (J E Smith) (Lepidoptera, Noctuidae), a new alien invasive pest in west and central africa. PLoS ONE 11:e0165632. https://doi. org/10.1371/journal.pone.0165632

González-Moreno A, Bordera S (2012) The Ichneumonidae (Hymenoptera: Ichneumonoidea) of Ría Lagartos Biosphere Reserve, Yucatán, Mexico. Zootaxa 3230:1. https://doi.org/10.11646/ zootaxa.3230.1.1

Gupta A, Lalitha Y, Varshney R, Shylesha AN, Van C (2020) Chelonus formosanus Sonan (Hymenoptera: Braconidae) an egglarval parasitoid of the invasive pest Spodoptera frugiperda (JE Smith) (Lepidoptera: Noctuidae) amenable to laboratory mass production in India. J Entomol Zool Stud 8(1):1521-1524

Hagen KS (1950) Fecundity of Chrysopa californica as affected by synthetic foods. J Econ Entomol 43:101-104. https://doi.org/10. 1093/jee/43.1.101
Hagen K (1953) A premating period in certain species of the genus Opius (Hymenoptera: Braco-nidae). Proc Hawaii Entomol Soc 15:115-116

Hajek AE, Hurley BP, Kenis M, Garnas JR, Bush SJ, Wingfield MJ, van Lenteren JC, Cock MJ (2016) Exotic biological control agents: a solution or contribution to arthropod invasions? Biol Invasions 18:953-969

Hay-Roe MM, Meagher RL, Nagoshi RN, Newman Y (2016) Distributional patterns of fall armyworm parasitoids in a corn field and a pasture field in Florida. Biol Control 96:48-56

Hoballah ME, Degen T, Bergvinson D, Savidan A, Tamo C, Turlings TC (2004) Occurrence and direct control potential of parasitoids and predators of the fall armyworm (Lepidoptera: Noctuidae) on maize in the sub-tropical lowlands of Mexico. Agric Entomol 6(1):83-88

Hoelmer KA, Kirk AA (2005) Selecting arthropod biological control agents against arthropod pests: can the science be improved to decrease the risk of releasing ineffective agents? Biol Control 34:255-264. https://doi.org/10.1016/j.biocontrol.2005.05.001

Hokkanen HMT, Babendreier D, Bigler F, Burgio G, Kuske S, van Lenteren JC, Loomans AJM, Menzler-Hokkanen I, van Rijn PCJ, Thomas MB, Tommasini MG, Zeng QQ (2003) Evaluating environmental risks of biological control introductions into Europe: final report of project EU-FAIR5-CT97-3489 ('ERBIC')

Howarth FG (1991) Environmental impacts of classical biological control. Annu Rev Entomol 36:485-509

Jourdie V, Alvarez N, Turlings TCJ (2008) Identification of seven species of hymenopteran parasitoids of Spodoptera frugiperda, using polymerase chain reaction amplification and restriction enzyme digestion. Agric for Entomol 10:129-136. https://doi. org/10.1111/j.1461-9563.2008.00362.x

Kenis M, Hurley B, HajekCock AEM (2017) Classical biological control of insect pests of trees-facts and figures. Biol Invasions 19:3401-3417

Kenis M, Du Plessis H, van den Berg J, Ba MN, Goergen G, Kwadjo KE, Baoua I, Tefera T, Buddie A, Cafà G, Offord L, Rwomushana I, Polaszek A (2019) Telenomus remus, a candi-date parasitoid for the biological control of Spodoptera frugiperda in Africa, is already present on the continent. Insects. https://doi. org/10.3390/insects 10040092

Knaak N, Fiuza LM (2005) Histopathology of Anticarsia gemmatalis Hübner (Lepidoptera; Noc-tuidae) treated with nucleopolyhedrovirus and Bacillus thuringiensis serovar kurstaki. Braz $\mathbf{J}$ Microbiol 36:196-200. https://doi.org/10.1590/S1517-83822 005000200017

Leius K (1963) Effects of pollens on fecundity and longevity of adult Scambus buolianae (Htg.) (Hymenoptera: Ichneumonidae). Can Entomol 95:202-207. https://doi.org/10.4039/Ent95202-2

López M, Rojas JC, Vandame R, Williams T (2002) Parasitoidmediated transmission of an iridescent virus. J Invertebr Pathol 80:160-170. https://doi.org/10.1016/S0022-2011(02)00106-4

Lynch LD, Thomas MB (2000) Nontarget effects in the biocontrol of insects with insects, nematodes and microbial agents: the evidence. Biocontrol News Inf 21:117-130

Marenco RA, Saunders JL (1993) Parasitoides del gusano cogollero, Spodoptera frugiperda (Lepdidoptera: Noctuidae) en maiz, Turrialba Costa Rica. Manejo Integrado De Plagas (costa Rica) 8:13-18

Meagher RL, Nuessly GS, Nagoshi RN, Hay-Roe MM (2016) Parasitoids attacking fall armyworm (Lepidoptera: Noctuidae) in sweet corn habitats. Biol Control 95:66-72. https://doi.org/10.1016/j. biocontrol.2016.01.006

Medina TMC, Camacho ZJE, Luque YP, Siabatto A (1988) Ciclo de vida y descripción de Chelo-nus insularis Cresson 
(Hymenoptera: Braconidae), parásito de Spodoptera spp. Rev Colomb Entomol 14:13-21

Melo IF, Penteado-Dias AM (2009) Estudo Qualitativo das Espécies de Eiphosoma Cresson, 1865 (Hymenoptera, Ichneumonidae, Cremastinae) em Ecossistemas Brasileiros. Em: 8a. Jornada Científica e Tecnológica da UFSCAR, 2009, São Carlos, SP, Anais, 2009

Melo I, Onody H, Penteado-Dias A (2012) New species of the Eiphosoma dentator (Fabricius, 1804) species-group (Hymenoptera, Ichneumonidae, Cremastinae) from Brazil. Environ Entomol 72:389-391. https://doi.org/10.1590/S1519-6984201200020002

Moher D, Liberati A, Tetzlaff J, Altman DG (2009) Preferred reporting items for systematic reviews and meta-analyses: the PRISMA statement. PLoS Med 6:e1000097. https://doi.org/10.1371/journ al.pmed.1000097

Molina-Ochoa J, Carpenter JE, Heinrichs EA, Foster JE (2003) Parasitoids and parasites of Spodoptera frugiperda (Lepidoptera; Noctuidae) in the Americas and Caribbean Basin: an inventory. Fla Entomol 86:254-289. https://doi.org/10.1653/0015-4040(2003) 086[0254:PAPOSF]2.0.CO;2

Molina-Ochoa J, Carpenter JE, Lezama-Gutiérrez R, Foster JE, González-Ramírez M, Angel-Sahagún CA, Farías-Larios J (2004) Natural distribution of hymenopteran parasitoids of Spodoptera frugiperda (Lepidoptera; Noctuidae) larvae in Mexico. Fla Entomol 87:461-472. https://doi.org/10.1653/00154040(2004)087[0461:NDOHPO]2.0.CO;2

Murúa MG, Molina-Ochoa J, Fidalgo P (2009) Natural distribution of parasitoids of larvae of the fall armyworm, Spodoptera frugiperda, in Argentina. J Insect Sci 9:20

Myers JH, Cory JS (2017) Biological control agents: invasive species or valuable solutions? In: Vilà M, Hulme P (eds) Impact of biological invasions on ecosystem services. Springer, Cham

Onody H, Melo I, Penteado-Dias A, Dias-Filho M (2009) New species of Eiphosoma Cresson 1865 (Hymenoptera, Ichneumonidae, Cremastinae) from Brazil. Braz J Biol 69:1205-1206. https://doi. org/10.1590/S1519-6984200900050002

Onody HC, Frizo de Melo I, Penteado-Dias AM (2012) Abundância, riqueza e diversidade de espécies de Eiphosoma Cresson 1865 (Hymenoptera, Ichneumonidae, Cremastinae) associada a hortas orgânicas. Idesia 30:115-120. https://doi.org/10.4067/S071834292012000100014

Ordóñez-García M, Rios-Velasco C, Berlanga-Reyes DI, Acosta-Muñiz CH, Salas-Marina MÁ, Cambero-Campos OJ (2015) Occurrence of natural enemies of Spodoptera frugiperda (Lepidoptera: Noctuidae) in Chihuahua, Mexico. Fla Entomol 98:843-847

Pair SD, Raulston JR, Sparks AN, Martin PB (1986) Fall armyworm (Lepidoptera: Noctuidae) parasitoids: differential spring distribution and incidence on corn and sorghum in the Southern United States and Northeastern Mexico. Environ Entomol 15:342-348. https://doi.org/10.1093/ee/15.2.342

Patel PN, Habib MEM (1982) Ocorrencia natural de aspergillus parasiticus em populacoes de Spodoptera frugiperda (Abbot $\&$ Smith, 1797) (Lepidoptera: Noctuidae) e sua trasmissao por insectos parasitos. Rev Agric Piracicaba 57:223-232

Patel PN, Habib MEM (1984) Levantamento e eficacia de insectos parasitos de Spodoptera frugi-perda (Abbot \& Smith, 1797) (Lepidoptera: Noctuidae). Rev Agric Bras 59:229-237

Patel PN, Habib MEM (1986) Survey and efficiency of insect parasites of Spodoptera frugiperda (Abbot \& Smith, 1797) (Lepidoptera, Noctuidae). Rev Agric 61:93-100

Penagos DI, Cisneros J, Hernández O, Williams T (2005) Lethal and sublethal effects of the natu-rally derived insecticide spinosad on parasitoids of Spodoptera frugiperda (Lepidoptera: Noc-tuidae). Biocontrol Sci Technol 15:81-95. https://doi.org/10.1080/09583 150400015987
Pérez-Kepp O (2007) El papel de los granulocitos en las reacciones de defensa interna de las larvas de Spodoptera frugiperda (Smith) (Lepidoptera: Noctuidae). In: Sociedad Venezolana de Entomología (ed) Resúmenes XX Congreso Venezolano de Entomología. Entomotropica, Universidad Nacional Experimental del Táchira, pp 64-65

Porter CC (1983) Eiphosoma dentator (Fabricius) in Florida (Hymenoptera: Ichneumonidae). Fla Entomol 66:353. https://doi.org/ $10.2307 / 3494130$

Raven K (1996) Orden Hymenoptera II: sub-orden Apocrita, Superfamilias Ichneumonoidea y Evanioidea. Universidad Nacional Agraria La Molina, Departamento de Entomología, p 80

Rebek EJ, Frank SD, Royer TA, Bogràn EC (2012) Alternatives to chemical control of insect pests. In: Soloneski S (ed) Insecticides—basic and other applications. IntechOpen. https://doi.org/ $10.5772 / 29887$

Rodriguez-Berrio A, Bordera S, Sääksjärvi I (2009) Checklist of Peruvian Ichneumonidae (Insecta, Hymenoptera). Zootaxa 2303:1-44

Ruíz-Cancino E, Kasparyan DR, Coronado Blanco JMA, Myartseva SN, Trjapitzin VA, Hernández Aguilar SG, García Jiménez J (2010) Himenópteros de la Reserva "El Cielo", Tamaulipas, México. Dugesiana 17:53-71. https://doi.org/10.32870/duges iana.v17i1.3942

Rwomushana I, Bateman M, Beale T, Beseh P, Cameron K, Chiluba M, Clottey V, Davis T, Day R, Early R, Godwin J, Gonzalez-Moreno P, Kansiime M, Kenis M, Makale F, Mugambi I, Murphy S, Nunda W, Phiri N, Pratt C, Tambo J (2018) Fall armyworm: impacts and implications for Africa. Evidence Note Update. https://www.invasive-species.org/wp-content/ uploads/sites/2/2019/02/FAW-Evidence-Note-October-2018. pdf. Accessed 4 Mar 2021

Salas-Marina MA, Hernández-García V, Cruz-Macías WO, CamposSaldaña RA, Ríos-Velasco C, Lule-Chávez AN, Salas-Muñoz S (2018) New records of Eiphosoma sp. and Pristomerus vulnerator (Hymenoptera: Ichneumonidae) as natural enemies of the fall armyworm (Lepidoptera: Noctuidae) on cultivated maize in Chiapas, Mexico. J Entomol Sci 53:569-571. https:// doi.org/10.18474/JES18-17.1

Sheahan M, Barrett CB (2017) Ten striking facts about agricultural input use in Sub Saharan Africa. Food Policy 67:12-25

Shimbori EM, Onody HC, Fernandes DRR, Silvestre R, Tavares MT, Penteado-Dias AM (2017) Hymenoptera "Parasitica" in the state of Mato Grosso do Sul, Brazil. Iheringia Sér Zool 107:343. https://doi.org/10.1590/1678-4766e2017121

Silva TC, Lemos RNS, Moreira AA, Araujo JRG, Medeiros FR, Castellani MA (2008) Parasitoids associated with Spodoptera frugiperda (Lepidoptera: Noctuidae) in corn in the state of Maranhao, Brazil. Boletín De Sanidad Vegetal, Plagas 34:493-500

Silva RBD, Cruz I, Figueiredo MDLC, Bortoni MA, Pereira AG, Melo IF, Camargo LF, Penteado-Dias AM (2012) Record of new species of parasitoids on larvae of Spodoptera frugiperda (J. E. Smith) (Lepidoptera: Noctuidae) and Dichomeris famulata Meyrick (Lepidoptera: Gelechiidae) in Maize (Zea mays L.) in Brazil. Revista Brasileira De Milho e Sorgo 11:115-119. https://doi.org/10.18512/1980-6477/rbms.v11n1p115-119

Silveira JCF, Sasaki ET, Forner MA, Honda MS, Calafiori MH (1987) Ocorrencia de parasitoides de Spodoptera frugiperda (J.E. Smith, 1797) em cultura de milho, em Espirito Santo do Pin-hal, SP. Ecossistema 12:41-44

Syme PD (1975) The effects of flowers on the longevity and fecundity of two native parasites of the European pine shoot moth in Ontario. Environ Entomol 4:337-346. https://doi.org/10. 1093/ee/4.2.337

Tambo JA, Day RK, Lamontagne-Godwin J, Silvestri S, Beseh PK, Oppong-Mensah B, Phiri NA, Matimelo M (2019) Tackling fall armyworm (Spodoptera frugiperda) outbreak in Africa: an 
analysis of farmers' control actions. Int J Pest Manag 69:1-13. https://doi.org/10.1080/09670874.2019.1646942

Townes H, Townes M (1966) A catalogue and reclassification of the neotropic Ichneumonidae. Science 158:107. https://doi.org/10. 1126/science.158.3797.107

USDA-FAS (2017) Mexico corn: adequate reservoir levels benefitting winter corn. https://ipad.fas.usda.gov/highlights/2017/03/ Mexico/index.htm. Accessed 22 Dec 2019

Valicente FH (1989) Levantamento dos inimigos naturais de Spodoptera frugiperda (J.E. Smith, 1797) (Lepidoptera: noctuidae) em diferentes regiões do estado de Minas Gerais. Soc Entomol Bras 18:119-130

Van Driesche RG, Bellows Jr TS (1996) Biology of arthropod parasitoids and predators. In: Biological control, 1st edn. Springer, pp 309-336

van Driesche R, Hoddle M (2016) Non-target effects of insect biocontrol agents and trends in host specificity since 1985 . CAB Rev. https://doi.org/10.1079/PAVSNNR201611044

van Driesche RG, Reardon R (2004) Assessing host ranges for parasitoids and predators used for classical biological control: a guide to best practice. Citeseer, Morgantown, p 242

van Driesche RG, Carruthers RI, Center T, Hoddle MS, Hough-Goldstein J, Morin L, Smith L, Wagner DL, Blossey B, Brancatini V, Casagrande R, Causton CE, Coetzee JA, Cuda J, Ding J, Fowler SV, Frank JH, Fuester R, Goolsby J, Grodowitz M, Heard TA, Hill MP, Hoffmann JH, Huber J, Julien M, Kairo MTK, Kenis M, Mason P, Medal J, Messing R, Miller R, Moore A, Neuenschwander P, Newman R, Norambuena H, Palmer WA, Pemberton R, Perez Panduro A, Pratt PD, Rayamajhi M, Salom S, Sands D, Schooler S, Schwarzländer M, Sheppard A, Shaw R, Tipping PW, van Klinken RD (2010) Classical biological control for the protection of natural ecosystems. Biol Control 54:S2-S33. https://doi.org/10.1016/j.biocontrol.2010.03.003

van Huis A (1981) Integrated pest management in the small farmer's maize crop in Nicaragua. Ph.D. dissertation. Med. Landb. Wageningen, The Netherlands, $\mathrm{p} 222$

Vírgen OE, Campos JC, Bermudez AR, Velasco CR, Cazola CC, Aquino NI, Cancino ER (2013) Parasitoids and entomopathogens of the fall armyworm Spodoptera frugiperda (Lepidoptera: Noctuidae) in Nayarit, Mexico. Southwest Entomol 38:339-344. https://doi.org/10.3958/059.038.0216

von Mérey G, Veyrat N, Mahuku G, Valdez RL, Turlings TCJ, D'Alessandro M (2011) Dispensing synthetic green leaf volatiles in maize fields increases the release of sesquiterpenes by the plants, but has little effect on the attraction of pest and beneficial insects. Phytochemistry 72:1838-1847. https://doi.org/10.1016/j. phytochem.2011.04.022

von Mérey GE, Veyrat N, Lange ED, Degen T, Mahuku G, Valdez RL, Turlings TCJ, D’Alessandro M (2012) Minor effects of two elicitors of insect and pathogen resistance on volatile emissions and parasitism of Spodoptera frugiperda in Mexican maize fields. Biol Control 60:7-15. https://doi.org/10.1016/j.biocontrol.2011. 09.010

Wagner DL (2009) Ode to Alabama: the meteoric fall of a once extraordinarily abundant moth. Am Entomol 55:170-173. https://doi. org/10.1093/ae/55.3.170

Wheeler GS, Ashley T, Andrews KL (1989) Larval parasitoids and pathogens of the fall armyworm in honduran maize. Entomophaga 34:331-340. https://doi.org/10.1007/BF02372472

Yaseen M, Bennet FD, Barrow RM (1981) Introduction of exotic parasites for control of Spodop-tera frugiperda in Trinidad, the eastern Caribbean and Latin America. In: Brathwaite CWD, Pollard GV (eds) Urgent plant pest and disease problems in the Caribbean. Proceedings of the first meeting of the society for plant protection in the Caribbean, held in Kingston, Jamaica from November-27, 1981. Inter-American Institute for Cooperation on Agriculture, Trinidad and Tobago

Yu DS, Van Achterberg K, Horstmann K (2005) World Ichneumonoidea 2004. Taxonomy, biology, morphology and distribution. CD/DVD. Taxapad, Vancouver, BC, Canada

Publisher's Note Springer Nature remains neutral with regard to jurisdictional claims in published maps and institutional affiliations. 